\title{
AQUATIC VASCULAR PLANTS FROM THE SANJIANG PLAIN, NORTHEAST CHINA
}

\author{
EкоKо, W. A. ${ }^{1,2,5}-$ YAO, Y. L. ${ }^{1,2,3^{*}}-$ SHAN, Y. Q. ${ }^{1,2}-$ LIU, B. ${ }^{4}-$ SHABANI, I. E. ${ }^{1,2,6}$ \\ ${ }^{I}$ Wetland Biodiversity Conservation and Research Center, Northeast Forestry University, Harbin \\ P.O. Box 150040, China
}

${ }^{2}$ College of Wildlife and Protected Area, Northeast Forestry University, Harbin P.O. Box 150040, China

${ }^{3}$ Hebei Key Laboratory of Wetland Ecology and Conservation, Hengshui P.O. Box 053000, China

${ }^{4}$ Northeast Institute of Geography and Agroecology, Chinese Academy of Sciences, Changchun 130102, China

${ }^{5}$ Department of Water and Forest, University of Kisangani, PO Box 2012 - Kisangani, Democratic Republic of the Congo

${ }^{6}$ Department of Biology, Faculty of Sciences, State University of Bukavu, P.O. Box 570 - Bukavu, Democratic Republic of the Congo

${ }^{*}$ Corresponding author

e-mail: yaoyunlong@nefu.edu.cn

(Received $21^{\text {st }}$ Dec 2020; accepted $3^{\text {rd }}$ Mar 2021)

\begin{abstract}
Sanjiang plain is recognized as a biodiversity hotspot in China, and knowledge of aquatic vascular plant species is essential for long-term wetland conservation programs. This investigation provided a checklist of aquatic vascular plants for the Sanjiang plain wetland, and information about the influences of water depth on their parameters. Based on the inventory, 149 species were identified, belonging to 86 genera, 44 families and 32 orders. Of these, Cyperales was the most diverse order with 26 species, followed by Graminalis (14 species). Cyperaceae and Gramineae were the most species-rich families (26 and 14 species, respectively). Carex and Polygonum were the most species-rich genera with 14 and 9 species, respectively. Our analyses displayed that the availability of water depth influenced the increased cover and height of aquatic vascular plants. Wetland conservation should be a high priority to prevent vascular plants in the Sanjiang plain.
\end{abstract}

Keywords: inventory, plant species, checklist, correlations, wetlands

\section{Introduction}

Diverse wetland types are naturally highly dynamic (Wang et al., 2018), due to natural processes at the ecosystem level, e.g. seasonal and non-seasonal fluctuations of water levels, succession to other habitats, the lateral movement of rivers and the activity of large herbivores (Jian, 2008; Bilz et al., 2011). Wetlands play a vital role in maintaining biodiversity (Mitsch and Gosselink, 1993; Gopal and Junk, 2001), regulating regional micro-climate, maintaining groundwater level and cleaning air, and have a strong ability of water purification (Xiaomin, 1996; Herath, 2004; Jian, 2008; Chen et al., 2008; Zhang, 2010).

Wetlands have been modified since humans first started to grow crops and keep livestock (Wang et al., 2018), from minor diversions to form stock ponds up to hard defenses, channelization and damming of major rivers and streams (Bilz et al., 2011). 
Modification of wetland systems and complexes disrupts connections between populations by increasing the distance between patches further enhancing the probability of extinction (Bilz et al., 2011; Wang et al., 2018). Fragmentation of wetland habitats also leads to the decrease in total surface area (Wang et al., 2018), which affects the total size of wetland biodiversity, as well as the size of the remaining habitat patches increasing their vulnerability (Xiaomin, 1996; Jian, 2008; Bilz et al., 2011).

Aquatic plants provide a wide range of functions in freshwater ecosystems (Bilz et al., 2011). They supply the water with oxygen, fix atmospheric carbon, recycle nutrients, regulate water temperature and light, protect against erosion in flowing water and where the banks or margins are threatened by backwash from boat traffic (Murillo et al., 2009; Bilz et al., 2011). They also provide vital habitat and food for fish and aquatic invertebrates, which themselves support other animals and humans (Hamilton and Hamilton, 2006; Bilz et al., 2011). Their abundance, composition and productivity play key roles in the processes of wetland structure and functions (Janousek and Folger, 2013).

For centuries, most of wetland has been used by humans to produce food, and provide living space (Herath, 2004; Bilz et al., 2011). Consequently, vascular plant species are to a large extent dependent upon semi-natural habitats created and maintained by human activity (Liu et al., 2019), particularly traditional, non-intensive forms of land management (Bilz et al., 2011; Spyreas, 2019). Wetlands are under pressure from agricultural irrigation (Spaling, 1995; Wang and Sheng, 2005), urbanization (Liu et al., 2019), infrastructure development, tourism pressure, acidification, eutrophication and desertification (Yi et al., 1994; Mensing et al., 1998; Foley et al., 2005; Zhang, 2010; Bilz et al., 2011; Mahmood et al., 2014; Perugini et al., 2017). In China, $80 \%$ of the wetlands that once existed have been destroyed or degraded due to unsustainable use patterns (Lu, 2009), causing losses of biodiversity (Zhang, 2010).

Many vascular plant species are directly affected by overexploitation (Wang and Sheng, 2005), persecution and impacts of alien invasive species, as well as climate change being set to become an increasingly serious threat in the future (Bilz et al., 2011). The inventories on vascular plant diversity in temperate zone are still insufficient and will have to be based on collections, which is also an important objective of all herbaria in the world. In this study, we aimed (1) at providing a checklist of vascular plants; and (2) at assessing the correlations between vascular plant metrics and water depth in the Sanjiang Plain wetlands.

\section{Materials and methods}

\section{Research area and data collection}

The Sanjiang plain is located at $129^{\circ} 11^{\prime} \mathrm{E}-135^{\circ} 05^{\prime} \mathrm{E}$ and $43^{\circ} 49^{\prime} \mathrm{N}-48^{\circ} 27^{\prime} \mathrm{N}$ in Heilongjiang Province, Northeast China (Cui and Liu, 1999; Zhang, 2010; Liu et al., 2019). We collected data in summer of years 2016, 2017 and 2020 in two wetland sites of the Sanjiang plain, including the Qixing River Basin (Qixing River Nature Reserve and Sanhuan Pao Nature Reserve, which are connected) at east longitude

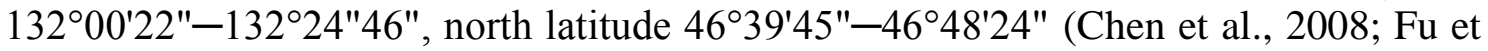
al., 2020), and the Sanjiang National Nature Reserve at east longitude $133^{\circ} 43^{\prime}-134^{\circ} 47^{\prime} \mathrm{E}$, north latitude $47^{\circ} 26^{\prime}-48^{\circ} 23^{\prime} \mathrm{N}$ (Teng et al., 2006).

The inventory was conducted on the wetland vegetation plots of $1 \mathrm{~m} \times 1 \mathrm{~m}$. A total of 194 and 385 sampling plots were investigated in the Qixing River Basin and Sanjiang National Nature Reserve, respectively. In each plot, water depth (m) was measured using 
longline method when aquatic vascular plant samples were investigated. And then the vascular plant metrics, include density (ind. $/ \mathrm{m}^{2}$ ) and cover $(\%)$ were recorded, and height of plants $(\mathrm{cm})$ was measured using Tape measure. In order to identify aquatic vascular plant species, we used identification keys of Steward (1958); Shengtian (2003); Yi (2008); Thiombiano et al. (2015); Wąsowicz (2020).

\section{Statistical analysis}

We computed mean values of plant density (ind. $\left./ \mathrm{m}^{2}\right)$, cover $(\%)$, height $(\mathrm{cm})$ and water depth $(\mathrm{cm})$ using paired t-test in R software (version 4.0.3) to compare these two wetland sampling sites (Qixing River Basin and Sanjiang National Nature Reserve).

Pearson correlation test was performed using RcmdrPlugin.FactorMineR package in R software (Kuhnert and Venables, 2005; Borcard et al., 2011) to evaluate the concordance between depth of water and vascular plant variables (density, cover and height). We calculated statistical significance at $* p$-value $<0.05$ and $* * p$-value $<0.01$.

\section{Results and discussion}

\section{List of aquatic vascular plant species in the wetlands of Sanjiang plain}

A total of 149 species of aquatic vascular plants were identified, belonging to 86 genera, 44 families and 32 orders. Of these, Cyperales was the most diverse order with 26 species, followed by Graminalis (14). Cyperaceae and Gramineae (Poaceae) were the most species-rich vascular plant families in the wetlands of the Sanjiang Plain (26 and 14 species, respectively). The most represented genera were Carex (14) and Polygonum (9) (Table 1). Our findings were consistent with checklists of Keddy (2000); Sieben et al. (2010); Zizka et al. (2015); dos Santos Oliveira et al. (2019) reporting that Cyperaceae and Gramineae were the families with the highest numbers of vascular plant species in the wetland habitats. The highest species-rich of these two families was probably due to the success in dispersion of sexual propagules (Santamaría, 2002) and ubiquitous distribution of species with relevant morphological characteristics that enable them to spread vegetatively (Goetghebeur, 1998).

We recorded 100 species in the Qixing River Basin and 80 species in the Sanjiang National Nature Reserve (Table 1). Our study showed that species richness was higher in the Qixing River Basin and differed significantly in both wetland sites (paired t-test, $p=0.0177$ ). That may be due to the fact that more species have been collected in deeper waters in the Qixing River Basin than in the Sanjiang National Nature Reserve (paired t-test, $p=0.001 ;$ Fig. $1 d$ ).

Table 1 showed that 31 species were identified in both sites; include Alisma plantagoaquatica, Artemisia atrovirens, Caltha palustris, Carex appendiculata, Carex pseudocuraica, Cirsium japonicum, Comarum palustre, Calamagrostis angustifolia, Equisetum fluviatile, Galium aparine, Glyceria spiculosa, Hypericum japonicum, Inula japonica, Iris laevigata, Lysimachia davurica, Lythrum salicaria, Menyanthes trifoliata, Nuphar pumilum, Nymphoides peltata, Phragmites australis, Polygonum hydropiper, Polygonum thunbergii, Sagittaria trifolia, Salvinia natans, Scirpus validus, Sium suave, Stachys baicalensis, Stellaria filicaulis, Stellaria radians, Typha orientalis, and Zizania iatifolia. 
Table 1. Aquatic vascular plant species list from the Sanjiang plain, Northeast China

\begin{tabular}{|c|c|c|c|c|}
\hline Order & Family & Species & QRB & SNNR \\
\hline \multirow[t]{8}{*}{ Alismatales } & Najadaceae & Najas minor & 1 & \\
\hline & Araceae & Lemna minor & & 1 \\
\hline & Alismataceae & Alisma plantago-aquatica & 1 & 1 \\
\hline & & Sagittaria trifolia & 1 & 1 \\
\hline & Butomaceae & Butomus umbellatus & 1 & \\
\hline & Potamogetonacaea & Potamogeton crispus & 1 & \\
\hline & & Potamogeton natans & 1 & \\
\hline & & Potamogeton perfoliatus & 1 & \\
\hline Acorales & Acoraceae & Acorus calamus & 1 & \\
\hline Apiales & Apiaceae & Sium suave & 1 & 1 \\
\hline \multirow[t]{3}{*}{ Asparagales } & Iridaceae & Belamcanda chinensis & 1 & \\
\hline & & Iris laevigata & 1 & 1 \\
\hline & Orchidaceae & Habenaria sagittifera & & 1 \\
\hline \multirow[t]{9}{*}{ Asterales } & Asteraceae & Achillea millefolium & & 1 \\
\hline & & $\begin{array}{l}\text { Aster tataricus } \\
\text { Bidens bipinnata }\end{array}$ & 1 & 1 \\
\hline & & $\begin{array}{l}\text { Blaens bipinnata } \\
\text { Bidens pilosa }\end{array}$ & 1 & 1 \\
\hline & & Carduus crispus & & 1 \\
\hline & & Centipeda minima & & 1 \\
\hline & & Saussurea salicifolia & 1 & \\
\hline & & Sonchus arvensis & 1 & \\
\hline & & Xanthium sibiricum & 1 & \\
\hline & Menyanthaceae & Nymphoides peltata & 1 & 1 \\
\hline Brassicales & Brassicaceae & Rorippa globosa & & 1 \\
\hline Callitrichales & Callitrichaceae & Callitriche palustris & & 1 \\
\hline \multirow[t]{11}{*}{ Campanulales } & Compositae & Artemisia annиa & 1 & \\
\hline & & Artemisia atrovirens & 1 & 1 \\
\hline & & Artemisia aurata & 1 & \\
\hline & & Artemisia lavandulaefolia & 1 & \\
\hline & & Artemisia mongolica & 1 & \\
\hline & & Artemisia rubripes & 1 & \\
\hline & & Artemisia scoparia & 1 & \\
\hline & & Cirsium japonicum & 1 & 1 \\
\hline & & Cirsium setosum & 1 & \\
\hline & & Inula japonica & 1 & 1 \\
\hline & & Inula salicina & 1 & \\
\hline \multirow[t]{5}{*}{ Caryophyllales } & Amaranthaceae & Chenopodium album & & 1 \\
\hline & & Chenopodium glaucum & & 1 \\
\hline & & Chenopodium hybridum & 1 & \\
\hline & Caryophyllaceae & Stellaria filicaulis & 1 & 1 \\
\hline & & Stellaria radians & 1 & 1 \\
\hline \multirow[t]{2}{*}{ Ceratophyllales } & Ceratophyllacaea & Ceratophyllum demersum & 1 & \\
\hline & & Ceratophyllum oryzetorum & 1 & \\
\hline \multirow{12}{*}{$\begin{array}{c}\text { Cucurbitales } \\
\text { Cyperales }\end{array}$} & Cucurbitaceae & Actinostemma tenerum & 1 & \\
\hline & Cyperaceae & Calamagrostis epigejos & 1 & \\
\hline & & Carex appendiculata & 1 & 1 \\
\hline & & Carex bohemica & 1 & \\
\hline & & Carex brownii & & 1 \\
\hline & & Carex cryptocarpa & 1 & \\
\hline & & Carex dispalata & & 1 \\
\hline & & Carex humida & 1 & \\
\hline & & Carex kirganica & 1 & \\
\hline & & Carex lasiocarpa & & 1 \\
\hline & & Carex limosa & 1 & \\
\hline & & Carex miyabei & 1 & \\
\hline
\end{tabular}




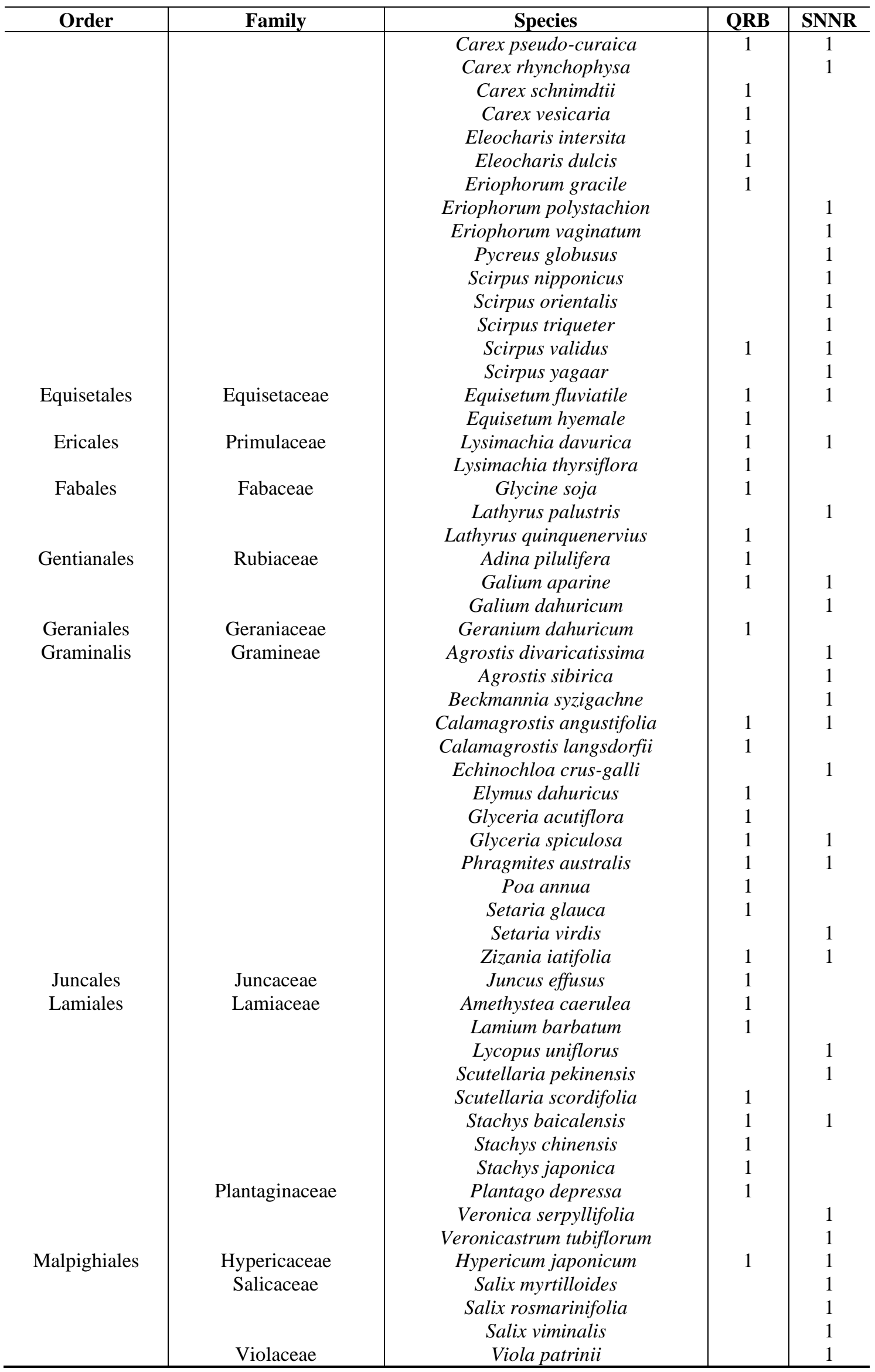




\begin{tabular}{|c|c|c|c|c|}
\hline Order & Family & Species & QRB & SNNR \\
\hline \multirow{6}{*}{$\begin{array}{c}\text { Menyanthes } \\
\text { Myrtales }\end{array}$} & & Viola phalacrocarpa & 1 & \\
\hline & Menyanthaceae & Menyanthes trifoliata & 1 & 1 \\
\hline & Lythraceae & Lythrum salicaria & 1 & 1 \\
\hline & & Trapa litwinowii & & 1 \\
\hline & Onagraceae & Epilobium angustifolium & 1 & \\
\hline & & Epilobium hirsutum & 1 & \\
\hline \multirow[t]{2}{*}{ Nymphaeales } & Nymphaeaceae & Nymphaea tetragona & 1 & \\
\hline & & Nuphar pumilum & 1 & 1 \\
\hline \multirow[t]{4}{*}{ Pandanales } & Typhaceae & Sparganium stoloniferum & 1 & \\
\hline & & Typha angustifolia & 1 & \\
\hline & & Typha minima & 1 & \\
\hline & & Typha orientalis & 1 & 1 \\
\hline \multirow[t]{9}{*}{ Polygonales } & Polygonaceae & Polygonum amphibium & 1 & \\
\hline & & Polygonum aviculare & & 1 \\
\hline & & Polygonum hydropiper & 1 & 1 \\
\hline & & Polygonum korshinskianum & & 1 \\
\hline & & Polygonum lapathifolium & & 1 \\
\hline & & Polygonum maackianum & & 1 \\
\hline & & Polygonum orientalis & & 1 \\
\hline & & Polygonum persicaria & & 1 \\
\hline & & Polygonum thunbergii & 1 & 1 \\
\hline Polypodiales & Thelypteridaceae & Thelypteris palustris & & 1 \\
\hline \multirow[t]{2}{*}{ Ranunculales } & Ranunculaceae & Anemone dichotoma & & 1 \\
\hline & & Caltha palustris & 1 & 1 \\
\hline \multirow[t]{9}{*}{ Rosales } & Rosaceae & Comarum palustre & 1 & 1 \\
\hline & & Potentilla chinensis & 1 & \\
\hline & & Sanguisorba officinalis & & 1 \\
\hline & & Sanguisorba parviflora & & 1 \\
\hline & & Sanguisorba teriuifolia & 1 & \\
\hline & & $\begin{array}{l}\text { Spiraea salicifolia } \\
\text { Vicia amoena }\end{array}$ & 1 & 1 \\
\hline & & Vicia cracca & 1 & \\
\hline & & Vicia japonica & 1 & \\
\hline & Urticaceae & Urtica cyanescens & & 1 \\
\hline Salviniales & Salviniaceae & Salvinia natans & 1 & 1 \\
\hline Saxifragales & Haloragaceae & Myriophyllum verticillatum & 1 & \\
\hline Scrophulariales & Lentibulariaceae & Utricularia vulgaris & 1 & \\
\hline Total & & & 100 & 80 \\
\hline
\end{tabular}

$\mathrm{QRB}=$ Qixing River Basin, SNNR $=$ Sanjiang National Nature Reserve, $1=$ present

\section{The comparison of mean values of vascular plant density, cover, height and water depth}

As shown in the Fig. $1 a-d$, the mean values of density (ind. $\left./ \mathrm{m}^{2}\right)$, cover $(\%)$, height $(\mathrm{cm})$ did not change significantly in these two wetland sampling sites (paired t-test, $p=0.2889$, $p=0.7113, p=0.4915$, respectively). While the environmental factor, water depth varied significantly in both wetland sites (paired t-test, $p=0.0017$ ). It was observed that Calamagrostis angustifolia (Gramineae) was species with high mean values of density in both sites, the Sanjiang National Nature Reserve with $\left(360\right.$ ind. $\left./ \mathrm{m}^{2}\right)$ and the Qixing River Basin (287 ind. $/ \mathrm{m}^{2}$ ). We recorded Zizania iatifolia (Gramineae) as species with high mean value of cover (89.67 \%) in the Sanjiang National Nature Reserve. While in the Qixing River Basin, Calamagrostis angustifolia (Gramineae) has been identified as species with high mean value of cover (50.99\%). In comparison to the height, Zizania iatifolia (Gramineae) had high mean values in both sites, the Sanjiang National Nature Reserve 
$(240.83 \mathrm{~cm})$ and the Qixing River Basin $(165.71 \mathrm{~cm})$. We registered species, Nuphar pumilum (Nymphaeaceae), in an average water depth more than $150 \mathrm{~cm}$ in the Qixing River Basin. While Zizania iatifolia (Gramineae) was recorded at $36.25 \mathrm{~cm}$ of water depth in the Sanjiang National Nature Reserve.
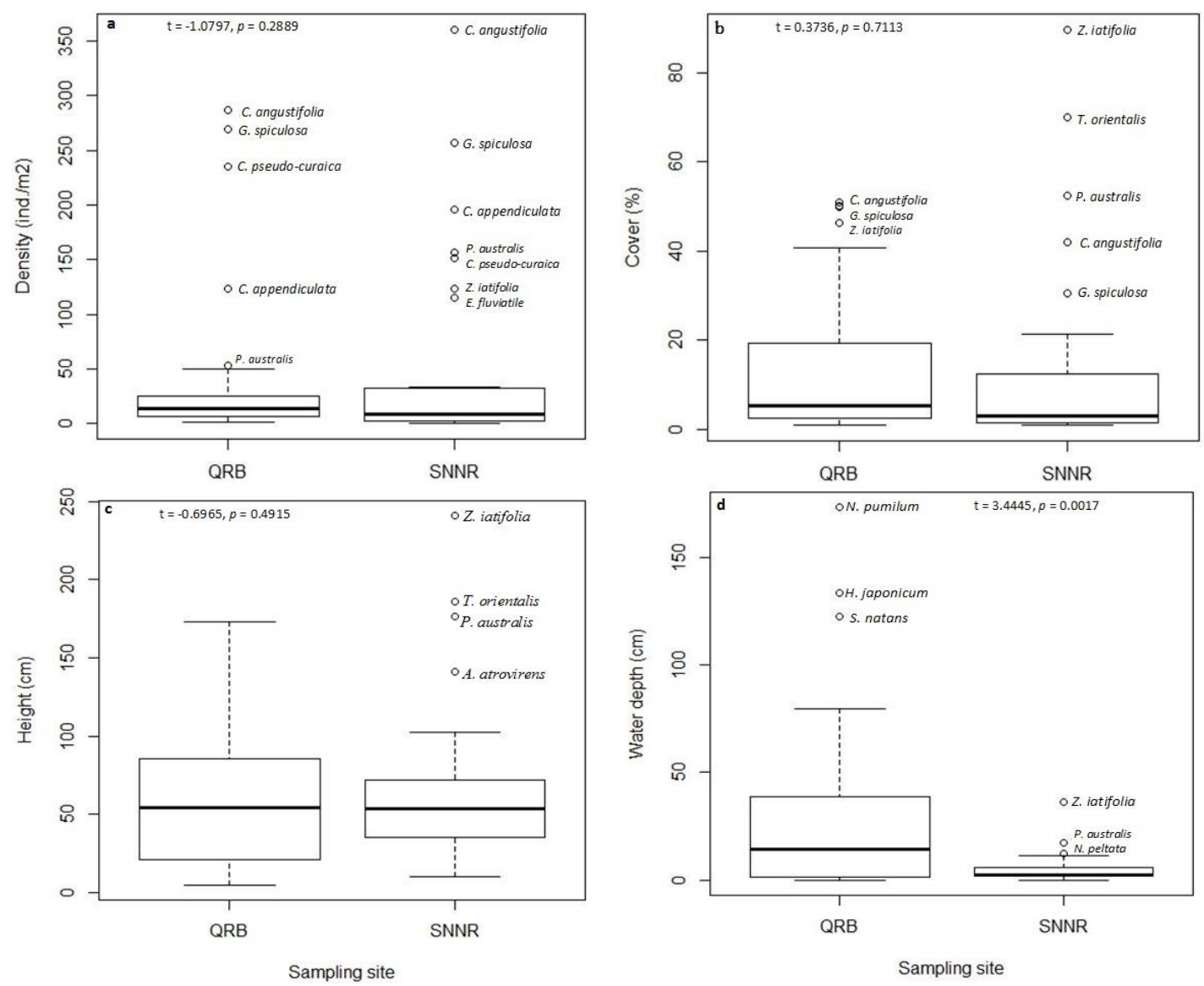

Figure 1. Comparison of mean values of a) density, $b$ ) cover, $c$ ) height and d) water depth of vascular plant species identified in both sampling sites. QRB = Qixing River Basin, SNNR = Sanjiang National Nature Reserve

Looking at the dominance, both wetland sites were dominated by Gramineae. Previous studies of Mbayngone et al. (2008); Ouédraogo et al. (2011); Assédé et al. (2012); Nacoulma (2012); Zizka et al. (2015); Seregin and Stepanova (2020) showed the same record that Gramineae was dominant family in the wetland biotopes. Due to human activity, original wetland, typically covered with Gramineae, degraded to marsh meadow and further to typical meadow land (Lu et al., 2007; Wang et al., 2018).

\section{Correlations of mean water depth and vascular plant variables}

Our analyses displayed that plant density did not change significantly with water depth in both wetland sites ( $p=0.6862$, Fig. $2 a$ and $p=0.1785$, Fig. $2 b$ ). Cover of plant was positively correlated with water depth $(r=0.4113, p=0.0214$, Fig. $2 c$ and $r=0.6367$, $p=0.0001$, Fig. $2 d$ ). The best model demonstrated that water depth had a significant effect on height of plant $(r=0.5009, p=0.0041$, Fig. $2 e$ and $r=0.5419, p=0.0016$, Fig. 2f). 


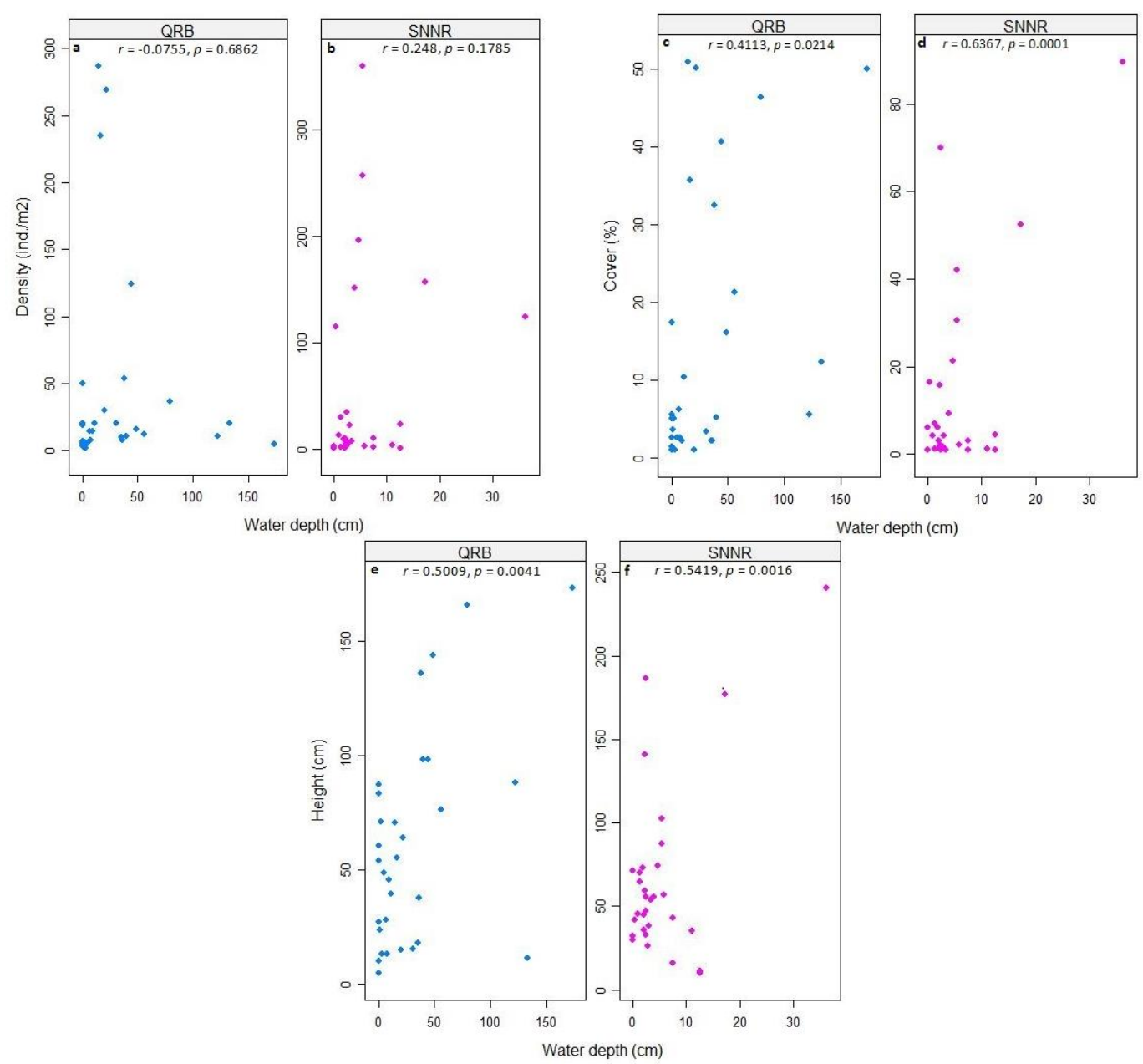

Figure 2. The relationships between water depth and vascular plant metrics of species identified in both reserves; a) density, b) cover and c) height. QRB = the Qixing River Basin, $S N N R=$ the Sanjiang National Nature Reserve

The results suggested that the availability of water depth influenced on vascular plant species population in the Sanjiang plain wetlands. Lu and He (2018) found that vascular plant species with high range size were more likely to be discovered in China.

Aquatic vascular plant families with temperate affinities (Crow, 1993; dos Santos Oliveira et al., 2019), like Potamogetonacaea and Haloragaceae were only collected in the Qixing River Basin. We recorded one plant species (Du et al., 2018), Glycine soja (Fabaceae), which is under national protection in the Qixing River Basin (NRIHP, QRWNRMS, 1999; Xianghua, 2007; Jian, 2008; Du et al., 2018). We suggest that its importance highlights the need for conservation approaches, and alternative livelihoods should be pressing for wetland protection in the Sanjiang plain (Zhou and Liu, 2005).

\section{Conclusion}

Overall, both wetland sites provided an important aquatic vascular plant species richness. Our analyses provided information that water depth could be one of the driver environmental parameters to influence the increase the cover and height of aquatic vascular plants, except the density. These data should be completed with further studies, 
which are required to assess the effects of other environmental factors on aquatic vascular plant metrics in order to grow databases and achieve long-term wetland conservation goals. The findings might recommend further studies on wetland plant diversity for setting conservation priorities; conservation status assessment of plant species and their common English names; and GIS mapping of wetland habitats and land-cover of the Sanjiang Plain.

Acknowledgements. This research was supported by Open Foundation of Hebei Key Laboratory of Wetland Ecology and Conservation (No. HKLK201907), which the authors gratefully acknowledge.

\section{REFERENCES}

[1] Assédé, P. S., Adomou, A. C., Sinsin, B. (2012): Magnoliophyta, Biosphere Reserve of Pendjari, Atacora province, Benin. - Check List 8: 642-661.

[2] Bilz, M., Kell, S. P., Maxted, N., Lansdown, R. V. (2011): European Red List of Vascular Plants. - Luxembourg: Publications Office of the European Union.

[3] Borcard, D., Gillet, F., Legendre, P. (2011): Numerical Ecology with R. - doi:10.1007/9781-4419-7976-6.

[4] Chen, Y. Q., Chang, D. H., Jin, L. S. (2008): The analyze of water quality of Qixinghe National Nature Reserve. - Modern agriculture Science and Technology 6: 235-238.

[5] Crow, G. E. (1993): Species diversity in aquatic angiosperms: latitudinal patterns. Aquatic Botany 44: 229-258.

[6] Cui, B. S., Liu, X. T. (1999): Ecological character changes and sustainability management of wetland in the Sanjiang Plain. - Areal Research and Development 18: 45-47.

[7] Dos Santos Oliveira, L., Andrade, B. O., Boldrini, I. I., de Chiara Moço, M. C. (2019): Aquatic vascular plants of South Brazil: checklist and a comparative floristic approach. Acta Botanica Brasilica 33(4): 709-715.

[8] Du, B., Zheng, Y., Liu, J., Mao, D. (2018): Threatened Plants in China's Sanjiang Plain: Hotspot Distributions and Gap Analysis. - Sustainability 10(2): 194.

[9] Foley, J. A., Defries, R., Asner, G. P., Barford, C., Bonan, G., Carpenter, S. R. (2005): Global consequences of land use. - Science 309(5734): 570-574.

[10] Fu, S., Xing, Z., Ji, Y., Zhao, Y., Sun, M., Li, H., Fu, Q. (2020): Improved flood simulation accuracy by downscaling remotely sensed precipitation data in the Qixing Wetland Watershed. - Ecological Engineering 158: 106038. doi:10.1016/j.ecoleng.2020.106038.

[11] Goetghebeur, P. (1998): Cyperaceae. - In: Kubitzki, K. (ed.) The families and genera of vascular plants. Volume IV - Flowering Plants - Monocotyledons: Alismatanae and Commelinanae (except Gramineae). Berlin/ Heidelberg, Springer.

[12] Gopal, B., Junk, W. J. (2001): Assessment, determinant, function and conservation of biodiversity in wetlands: Present status and future need. - In: Gopal, B., Junk, W. J., Davis, J. A. (eds.) Biodiversity in wetlands: Assessment, function and conservation. Leiden: Backhuys.

[13] Hamilton, A., Hamilton, P. (2006): Plant Conservation. An Ecosystem Approach. Earthscan, London.

[14] Herath, G. (2004): Incorporating community objectives in improved wetland management: the use of the analytic hierarchy process. - Journal of Environmental Management 70: 263273.

[15] Janousek, C. N., Folger, C. L. (2013): Variation in tidal wetland plant diversity and composition within and among coastal estuaries: assessing the relative importance of environmental gradients. - Journal of Vegetation Science 25(2): 534-545.

[16] Jian, S. (2008): The study on Qixinghe wetland nature reserve and rational utilization in Sanjiang Plain Areas. - Forestry Survey and Design 4: 44-45. 
[17] Keddy, P. A. (2000): Wetland ecology: Principles and conservation. - Cambridge, Cambridge University Press.

[18] Kuhnert, P., Venables, B. (2005): An Introduction to R: Software for Statistical Modelling \& Computing. - CSIRO Mathematical and Information Sciences, Cleveland, Australia.

[19] Liu, T., Yu, L., Zhang, S. (2019): Impacts of wetland reclamation and paddy field expansion on observed local temperature trends in the Sanjiang Plain of China. - Journal of Geophysical Research: Earth Surface 124: 414-426.

[20] Lu, Q., Ma, K. M., Zhang, J. Y. (2007): Soil nutrients of degraded wetland and farmland in Sanjiang plain. - Journal of Ecology and Rural Environment 23: 23-28.

[21] Lu, X. G. (2009): Types, distributions and functions of wetlands in China. - Landscape Design 2: 10-15.

[22] Lu, M., He, F. (2018): The patterns of vascular plant discoveries in China. - BioRxiv, the preprint server for biology. doi: https://doi.org/10.1101/381731.

[23] Mahmood, R., Sr. Pielke, R. A., Hubbard, K. G., Niyogi, D., Dirmeyer, P. A., McAlpine, C. (2014): Land cover changes and their biogeophysical effects on climate. - International Journal of Climatology 34(4): 929-953.

[24] Mbayngone, E., Schmidt, M., Hahn-Hadjali, K., Thiombiano, A., Guinko, S. (2008): Magnoliophyta of the partial faunal reserve of Pama, Burkina Faso. - Check List 4: 251266.

[25] Mensing, D. M., Galatowitsch, S. M., Tester, J. R. (1998): Anthropogenic effects on the biodiversity of riparian wetlands of a northern temperate landscape. - Journal of Environmental Management 53: 349-377.

[26] Mitsch, W. J., Gosselink, J. G. (1993): Wetlands. - New York: Van Nostrand Reinhold.

[27] Murillo, P. G., Fernández-Zamudio, R., Cirujano, S. (2009): Habitantes del agua. Macrófitos. - Agencia Andaluza del Agua, Consejeria de Medio Ambiente, Junta de Andalucia.

[28] Nacoulma, B. M. I. (2012): Dynamique et stratégies de conservation de la végétation et de la phytodiversité du complexe écologique du parc national du W du Burkina Faso. - Thèse de doctorat, Université de Ouagadougou.

[29] NRIHP, QRWNRMS (1999): The Comprehensive Survey Report of Qixing River Wetland Nature Reserve. - The Natural Resources Institute of Heilongjiang Province, Qixing River Wetland Nature Reserve Management Station, Heilongjiang Province, China.

[30] Ouédraogo, O., Schmidt, M., Thiombiano, A., Hahn, K., Guinko, S., Zizka, G. (2011): Magnoliophyta, Arly National Park, Tapoa, Burkina Faso. - Check List 7: 85-100.

[31] Perugini, L., Caporaso, L., Marconi, S. (2017): Biophysical effects on temperature and precipitation due to land cover change. - Environmental Research Letters 12(5): 053002.

[32] Santamaría, L. (2002): Why are most aquatic plants widely distributed? Dispersal, clonal growth and small-scale heterogeneity in a stressful environment. - Acta Oecologica 23: 137-154.

[33] Seregin, A. P., Stepanova, N. Y. (2020): MHA Herbarium: Eastern European collections of vascular plants. - Biodiversity Data Journal 8: e57512.

[34] Shengtian, Z. (2003): The Flora of Qixinghe Wetland Nature Reserve. - Heilongjiang, China.

[35] Sieben, E. J., Morris, C. D., Kotze, D. C., Muasya, A. M. (2010): Changes in plant form and function across altitudinal and wetness gradients in the wetlands of the MalotiDrakensberg, South Africa. - Plant Ecology 207: 107-119.

[36] Spaling, H. (1995): Analyzing cumulative environmental effects of agricultural land drainage in southern Ontario, Canada. - Agriculture Ecosystems and Environment 53: 279-292.

[37] Spyreas, G. (2019): Floristic Quality Assessment: a critique, a defense, and a primer. Ecosphere 10(8).

[38] Steward, A. N. (1958): Manual of vascular plants of the Lower Yangtze Valley, China. Curator of the Herbarium, Oregon State College Corvallis. 
[39] Teng, L-W., Liu, Z-S., Zhang, E-D., Ma, J-Z. (2006): Winter bedding site selection by the Roe Deer (Capreolus capreolus) in Sanjiang National Nature Reserve, Heilongjiang Province, China. - Zoological Research 27(4): 403-410.

[40] Thiombiano, A., Schmidt, M., Dressler, S., Ouédraogo, A., Hahn, K., Zizka, G. (2015): Catalogue des plantes vasculaires du Burkina Faso. - Boissiera 65.

[41] Wang, Y. Y., Sheng, L. X. (2005): Outlook for international wetland ecology research: the $7^{\text {th }}$ INTECOL international wetlands conference and its inspirations on China. - Geography and Geoinformation Science 21: 56-59.

[42] Wang, J., Li, M., Zhang, T., Sui, X., Ma, W., Ni, H. W. (2018): Assessment of microbial diversity of Deyeuxia angustifolia wetland through phospholipid fatty acids (PLFA) in Sanjiang Plain. - International Journal of Agriculture and Biology 20: 1463-1470.

[43] Wąsowicz, P. (2020): Annotated checklist of vascular plants of Iceland. - Fjölrit Náttúrufræðistofnunar nr. 57. Garðabær: Náttúrufræðistofnun Íslands.

[44] Xianghua, L. (2007): The Evaluation of relatively use value in Qixinghe wetland. Environmental and Sustainable Development 3: 24-26.

[45] Xiaomin, L. (1996): The agriculture development and wildlife species diversity conservation in Sanjiang Plain Areas. - Wild Animal 5: 16-19.

[46] Yi, G., Risley, D., Koneff, M., Davis, C. (1994): Development of Ohio's GIS-based wetlands inventory. - Journal of Soil and Water Conservation 49(1): 23-28.

[47] Yi, F. K. (2008): Wetland wild vascular plants in Northeastern China. - Northeast Institute of Geography and Agroecology, Chinese Academy of Science.

[48] Zhang, C., Robinson, D., Wang, J., Liu, J., Liu, X., Tong, L. (2010): Factors Influencing Farmers' Willingness to Participate in the Conversion of Cultivated Land to Wetland Program in Sanjiang National Nature Reserve, China. - Environmental Management 47(1): 107-120.

[49] Zhou, Z-Q., Liu, T. (2005): The current status, threats and protection way of Sanjiang Plain wetland, Northeast China. - Joumal of Forestry Research 16(2): 148-152.

[50] Zizka, A., Thiombiano, A., Dressler, S., Nacoulma, B. M. I., Ouédraogo, A., Ouédraogo, I., Ouédraogo, O., Zizka, G., Hahn, K., Schmidt, M. (2015): The Vascular Plant Diversity of Burkina Faso (West Africa) - A Quantitative Analysis and Implications for Conservation. - Candollea 70(1): 9-20. 